\title{
Epistemological positioning and evidentiality in English news discourse: A text-driven approach*
}

MONIKA BEDNAREK

\section{Abstract}

This paper uses a text-driven approach to explore epistemological positioning (the expression of assessments concerning knowledge) in English newspapers. The notion of epistemological positioning (EP) often overlaps with evidentiality - the linguistic marking of the basis of speaker/writer knowledge. This is a relatively modern concept in linguistics and, compared to the amount of research it has attracted concerning other languages, it has been somewhat neglected in research focusing on English. Newspaper texts are a particularly good source for looking into EP and evidentiality, because the news story is a genre that is preoccupied with knowledge. The analysis shows that EP in English can be very complex, and that the distinction between attribution and averral (Sinclair 1988) needs to be taken into account when discussing it in naturally occurring texts (particularly in news texts). The resulting elements of EP that are identified for the English language offer a first glance at the possibilities to express EP in English, and open up future research on EP in different registers and text types.

Keywords: epistemological positioning; evidentiality; attribution; averral; subjectivity; news discourse.

\section{Introduction}

This paper is about the linguistic expression of assessments concerning knowledge, exploring what is here called epistemological positioning (EP). Epistemological positioning deals with questions such as 'Who is the source of information?', 'What is the basis of someone's (the writer's or a third party's) knowledge?', 'How certain is their knowledge?' etc. ${ }^{1}$ EP thus overlaps partly with the notion of evidentiality - the linguistic marking of evidence. This is a concept that has largely been applied to 
languages other than English (see Section 2), even though it appears that expressions of evidentiality have a variety of important pragmatic functions. This paper aims to direct linguistic attention to epistemological positioning as an object worthy of further research and systematization of analysis. In Section 2, I discuss the connection between evidentiality and EP. Section 3 gives a brief introduction to the text-driven approach of this paper (3.1); outlines the connection between sourcing (attribution/ averral), evidentiality, and subjectivity (3.2 and 3.3); and considers epistemological reasoning (backing) to a certain extent (3.4). Section 4 gives a brief conclusion and a suggested outline of elements of EP that need to be considered in the analysis of naturally occurring discourse.

\section{Evidentiality and epistemological positioning}

Initially, the concept of evidentiality originated with the early Americanists (Boas, Sapir, Swadesh, Hoijer), but the term evidential was probably introduced by Roman Jakobson (1971 [1957]) as a provisional label for a verbal category that indicates the basis of the information on which a speaker's/writer's statement is based (Jacobsen 1986: 3-7; Bybee and Fleischman 1995: 13). However, as Comrie (2000: 1) points out, it was only in the mid to late 1980 s that a swell in interest in evidentiality occurred (e.g., Givón 1982; Chafe and Nichols 1986; Willet 1988), which has resurged in the mid to late 1990s (e.g., Hill and Irvine 1993b; DeLancey 1997), and appears still to be going on (recent research includes Johanson and Utas 2000; Mushin 2001; Aikhenvald and Dixon 2003; Aikhenvald 2004). Evidentiality and markers of evidentiality, evidentials, are nowadays defined in diverse ways; ${ }^{2}$ however, broadly speaking, two main approaches can be distinguished (as first suggested by Chafe 1986).

In a narrow definition, 'evidentials express the kinds of evidence a person has for making factual claims' (Anderson 1986: 273). Included are linguistic forms that mark the speaker's/writer's basis of knowledge as something seen, heard, inferred, or told (see, e.g., Du Bois 1986; Hill and Irvine 1993a). ${ }^{3}$ Often, such research regards only grammaticalized expressions as evidentiality (e.g., Aikhenvald 2004: 6), in particular evidential morphemes. As Mushin (2001: 35) notes, '[t]he linguistic study of evidentiality has been primarily concerned with the status of evidential forms and evidential meanings in morphological systems'. This results in the quasi-total exclusion of the English language from such (mostly typological) research. Thus we can find that the majority of research on evidentiality in fact deals with languages other than English, usually more 
'exotic' languages such as Albanian, Northern Iroquoian, Wintu, and many others (compare Chafe and Nichols 1986; Guentchéva 1996; Johanson and Utas 2000; Dendale and Tasmowski 2001; Aikhenvald and Dixon 2003; for more studies see de Haan's 2001 bibliography on evidentiality and the references in Aikhenvald 2004). Compared to this wealth of research, there are only a few studies investigating the concept of evidentiality in the English language. ${ }^{4}$

In a broader definition, the term evidential has come to '[cover] much more than the marking of evidence per se' (Chafe and Nichols 1986: vii). In this approach, evidentiality, or epistemological stance, as Mushin (2001) calls it, involves various 'attitudes towards knowledge' (Chafe 1986: 262), and evidence is only one of the epistemological considerations that are linguistically encoded (Chafe 1986: 262). Evidentiality in this sense is concerned with matters of truth, certainty, doubt, reliability, authority, confidence, personal experience, validity, inference, reporting, factual and imaginative stance, evidence, confirmation, surprise, and expectedness (Chafe and Nichols 1986; Caffi and Janney 1994; Stubbs 1996; Mushin 2001).

Any researcher addressing the notion of evidentiality must thus ask him/herself whether to adopt the narrow or the broad view of evidentiality (Mushin 2001: 51). If we consider evidentiality in its narrow definition, it is only one part of the greater study of epistemological positioningthat aspect of EP that marks the basis of the speaker's/writer's knowledge. Concerning evidentiality in its broader definition, there is much more overlap with the concept of epistemological positioning. However, I prefer using the term epistemological positioning (rather than evidentiality), because of the etymological roots involved (epistemological derives from Greek epistēmē, 'knowledge', whereas evidential automatically calls up notions of evidence). This also reduces terminological confusion and might help us to distinguish more clearly between different types of 'attitudes towards knowledge', offering a sharper perspective. Furthermore, it is convenient to have available the usage of the term evidentiality to refer to a specific subcategory of EP, that of marking evidence (for criticism of evidentiality in a broad definition, cf. also Aikhenvald 2003: 19). ${ }^{5}$ On the other hand, the research by Chafe and others provides a useful springboard for the analysis of EP. Thus, it could be suggested that epistemological positioning involves at least the following elements (cf. in particular Chafe 1986; Biber et al. 1999):

- Basis of knowledge (evidentiality): was it seen, inferred, heard, etc.?

- Certainty of knowledge (epistemic modality): how certain is the speaker/writer of his/her knowledge? 
- Deviations from knowledge (mirativity): is what the speaker/writer describes expected or unexpected in terms of his/her knowledge of the world? 6

- Extent: is the knowledge limited in some way?

Linguistically, evidentiality is, for example, expressed by evidential adverbs such as clearly, notoriously, or famously; mirativity (DeLancey 1997) can be expressed by 'expectational' adverbs such as amazingly, surprisingly; and extent of knowledge can be marked by adverbs and propositional phrases (generally, in most cases). Certainty of knowledge can either be directly expressed through the use of epistemic modal expressions (may, perhaps, must) or indirectly marked by evidential expressions: ${ }^{7}$ the reason for this is that there is a connection (but no direct correlation) between the type of evidence that is given and certainty of knowledge. In Chafe's (1986: 266) words: 'mode of knowing implies something about reliability' (compare also Willett 1988). For instance, it is assumed by researchers that direct evidence (e.g., visual data) is considered by speakers to be "the most certain kind of knowledge' (Sweetser 1984: 13).

In this paper I mainly want to consider bases of writer knowledge (evidentiality), though certainty of knowledge (modality) will also play a role. Mirativity and extent of knowledge, however, will not be considered here (see Bednarek 2006a for a discussion of un/expectedness). I will also connect the notion of evidentiality to the concept of sourcing, a concept that is crucial to news discourse and needs to be introduced in order to discuss EP in naturally occurring text data. Sourcing gives us an answer to one of the important questions that readers may ask of a news text: 'to whom can this be attributed?'

\section{Epistemological positioning, sourcing, and subjectivity}

\subsection{A text-driven approach to EP in English}

In order to find out more about what kinds of epistemological categories can be expressed in the English language, I manually analyzed a corpus of 70,000 words of British English newspaper reportage (see Table 1 in Appendix). This kind of approach represents a text-driven methodology, trying to make as few theoretical assumptions as possible before analyzing the text data, rather than using a previously established theoretical framework to classify the data (e.g., Chafe's categories). I use the term text-driven in analogy to Tognini-Bonelli's distinction between corpusdriven and corpus-based linguistics. The term corpus-based is employed 'to refer to a methodology that avails itself of the corpus mainly to expound, 
test or exemplify theories and descriptions that were formulated before large corpora became available to inform language study' (TogniniBonelli 2001: 65), and the term corpus-driven refers to an approach where 'the commitment of the linguist is to the integrity of the data as a whole, and descriptions aim to be comprehensive with respect to corpus evidence' (2001: 84). In analogy, the term text-driven refers to a methodology that is based on the manual analysis of small-scale text corpora rather than to an approach that is based on automated large-scale corpus analyses. ${ }^{8}$ In other words, I went through the corpus 'hunting' for expressions relating to EP (focusing mainly on evidentiality), without categorizing them in more detail on an a priori basis. Newspaper texts are a particularly good source for researching EP, because the news story is a genre that is preoccupied with knowledge. Therefore, the analysis of the corpus presumably gives us a good first glance at the possibilities to express EP in English. However, there is no assumption that the categories found in this corpus are exhaustive or cover all means of expressing EP in English (i.e., are representative of the English language as a whole). In any case, the concept of EP needs more elaboration, incorporating research from cognitive linguistics and philosophy concerning knowledge and knowledge structures.

\subsection{Sources and bases of propositions}

Before looking at the text data in more detail, it is useful to make a basic distinction between the sources and bases of propositions. In the following, source of propositions refers to the source to which knowledge can be attributed (who is 'responsible' for the content of the modified utterance). In contrast, basis of propositions concerns the basis (or evidence) for the source's knowledge (confusingly, the term source is usually used in evidentiality studies for such evidence, but, as will be seen presently, it is useful to distinguish clearly between these two notions). For example, in the utterance But some visibly flinched as he stooped to gutter politics with vicious personal attacks on political opponents, the source of the information is the writer and the basis of his/her knowledge is sensory evidence (visibly).

Thus, the first concept to be addressed is sourcing: who is mentioned as the source of a proposition in news reportage? Ordinarily, the source is either the writer (Self) as in Example (1) or a third party (Other) as in Example (2) (cf. also Hunston 2000: 190):

(1) Pelé, perhaps the greatest-ever footballer,.... (Times)

$\rightarrow$ Source $=$ Self (the writer) 
(2) 'The whips will be on the phone over the weekend to all the constituency chairmen of those who have been identified as being involved in the plot,' said one source. (Express)

$\rightarrow$ Source $=$ Other (one source)

The next question to be addressed is the basis of the source's (Self or Other) knowledge (evidentiality). On the basis of the corpus, the following bases of knowledge were identified:

- PERCEPTION

- GENERAL KNOWLEDGE

- PROOF

- OBVIOUSNESS

- UNSPECIFIED

These categories will now be discussed in more detail with the help of examples. The category of PERCEPTION encompasses three different kinds of perception that have been reduced to one general parameter for methodological purposes: 'mental perception' (Greenbaum 1969: 205) or inference (seem, appear, look), sensory perception (look, see, visibly, audibly), and 'showing' (reveal, show, betray, confirm). Mental perception shades into sensory perception in many cases, and the difference between sensory perception and showing is predominantly one of construal. Here are some examples of PERCEPTION evidentials from the corpus:

(3) MacDonald, dubbed the Queen of Tarts, looked distraught as the verdict was read out in a Paris court on her 44th birthday. (Express) (sensory perception)

(4) But some visibly flinched as he stooped to gutter politics with vicious personal attacks on political opponents. (Mirror) (sensory perception)

(5) Terrorists appear to have adopted a sinister new tactic in Iraq after a Western-looking suicide bomber tried to wipe out the country's fledgling government and U.S. security staff. (Mail) (mental perception or inference)

Concerning GENERAL KNOWLEDGE, the propositional content of what is modified is marked as based on what is regarded as part of the communal epistemic background shared by the audience and the writer (famously, infamously), whereas PROOF relates to a marking of the proposition as being based on some sort of 'hard proof' (tests found): 
(6) Mr Burrell, who Diana famously called her 'rock', said:.... (Independent)

(7) Twelve years after Gerald Ratner infamously described some of his jewellery as 'total crap', the boss of Britain's biggest credit card company yesterday stunned his customers with what appeared to be a similar vote of no confidence in his own product. (Guardian)

(8) Tests found he was driving at almost $70 \mathrm{mph}$ and was more than three times over the legal alcohol limit. (Express)

Concerning the category of OBVIOUSNESS, this refers to expressions such as clearly, which suggest that the basis of the writer's knowledge lies in the obviousness or self-evidence of what is modified (other candidates for this category are thus expressions such as obvious(ly) or plain(ly), which, however, do not occur in the corpus). The meaning of this category is very close to that of PERCEPTION, and can be paraphrased as 'not needing evidence' (for a different interpretation of clearly, see Bednarek 2006b). Some examples are:

(9) Tory leader Iain Duncan Smith shakes his fist defiantly yesterdayjust as his media advisers clearly told him to. (Sun)

(10) Although the ovations were clearly stage-managed, there was genuine sympathy in the Blackpool conference hall for a man who has been under the severest strain all week. (Times)

The next category, UNSPECIFIED, is the most problematic in that it only relates to one expression found in the corpus, namely it emerged that (which, however, occurs several times):

(11) It also emerged Hollywood is planning a movie on her life. (Mirror)

This expression indicates that there is some sort of basis for the modified proposition, without stating explicitly what this basis is: emerge is defined as follows: 'If a fact or result emerges from a period of thought, discussion or investigation, it becomes known as a result of it' (COBUILD 2001). It is not clear whether thought, discussion, or investigation are the bases of the proposition at hand; this remains inexplicit and may only occasionally be inferred from the context. More research is needed on this category in order to refine it. If there is only one expression (emerge) that can be included in this category, it might be better to categorize this expression as indicating GENERAL KNOWLEDGE (since what emerges 'becomes known as a result of it'). If there are other expressions with similar 
meanings (turn out might be a candidate), the establishment of a separate category (UNSPECIFIED) may be justified.

\subsection{The interplay of sourcing and evidentiality: Attribution and averral}

There is in fact a great amount of interaction between sourcing and evidentiality. To discuss this, the notions of attribution and averral are very useful. This distinction is adopted from Hunston (2000), drawing herself on Sinclair (1988). As she puts it, '[i]f a piece of language [...] is attributed, it is presented as deriving from someone other than the writer. If a piece of language is averred, the writer him or herself speaks' (Hunston 2000: 178). For example, an utterance such as John is an idiot is an averral, whereas within an utterance such as Paul said that John is an idiot, the proposition John is an idiot is attributed to Paul. Averral and attribution may be present in one and the same utterance, and the distinction is made even more complicated by the fact that "every attribution is also averred' (Hunston 2000: 179), i.e., that 'every attribution is embedded within an averral' (2000: 179). Thus, in Example ( $\left.2^{\prime}\right)$, the writer is the ultimate source of the entire utterance:

$\left(2^{\prime}\right)$ 'The whips will be on the phone over the weekend to all the constituency chairmen of those who have been identified as being involved in the plot,' said one source. (Express)

At the same time, the proposition 'The whips will be on the phone over the weekend to all the constituency chairmen of those who have been identified as being involved in the plot,' is attributed to one source. Ultimately, it is the writer who is responsible for this act of attribution, but it is the source that is said to be responsible for the attributed proposition. In other terms:

The writer avers that

'The whips will be on the phone over the weekend to all the constituency chairmen of those who have been identified as being involved in the plot,' said one source,

(source $=$ Self), and within this averral attributes the proposition

'The whips will be on the phone over the weekend to all the constituency chairmen of those who have been identified as being involved in the plot,' to a third party (source of embedded proposition $=$ Other).

In a strict sense, the attributed proposition is thus both part of an averral and at the same time an attribution. Expressions of EP can be found concerning both the averral (source $=$ Self) and the attribution (source $=$ Other): 
$\left(2^{\prime}\right)$ 'The whips will be on the phone over the weekend to all the constituency chairmen of those who have been identified as being involved in the plot,' said one source.

$\rightarrow$ source of utterance $=$ Self (writer)

$\rightarrow$ basis of Self's knowledge of attributed proposition $=$ HEARSAY

$\rightarrow$ certainty of Self's knowledge $=$ not explicitly marked

$\left(2^{\prime}\right)$ The whips will be on the phone over the weekend to all the constituency chairmen of those who have been identified as being involved in the plot

$\rightarrow$ source of proposition $=$ Other

$\rightarrow$ basis of Other's knowing $=$ not given

$\rightarrow$ certainty of Other's knowledge that whips be on the phone $=$ high $(\text { will })^{9}$

In this example, the writer tells us that $\mathrm{s} /$ he has knowledge of the proposition The whips ... plot because someone said so (his/her knowledge is based on HEARSAY), but does not comment explicitly on the certainty of his/her knowledge (said is neutral in this respect) or give other information concerning epistemological considerations. $\mathrm{S} /$ he sources the proposition The whips ... plot to an unnamed Other (one source), but gives no information about the basis of this Other's knowledge. There is, however, an expression of EP considering the certainty of this Other's knowledge that the whips ... be on the phone over the weekend (will is a modal that indicates high certainty).

Stating that the source of an utterance is not Self but Other can of course itself be interpreted as giving information about the basis of Self's knowledge. What the writer says is that his/her knowledge is in fact based on what a third party has either expressed linguistically (HEARSAY) or mentally (MINDSAY). In systemic-functional terms, an utterance can be marked as having been uttered by a 'Sayer' (Halliday and Matthiessen 2004: 252) (= HEARSAY/quoted speech), or as having been thought/felt/ experienced by a 'Senser' (2004: 201) (= MINDSAY/quoted mental experience). An example of HEARSAY has already been given above; here is an example of MINDSAY. Again, EP can concern the averral or the attribution:

(12) ... some smart Tories watching on TV thought the performance too 'mannered' to appeal to the wider audience at home. (Guardian)

$\rightarrow$ source of utterance $=$ Self

$\rightarrow$ basis of Self's knowledge of attributed proposition $=$ MINDSAY $/$ HEARSAY ${ }^{10}$

$\left(12^{\prime}\right)$ the performance [was] too 'mannered' to appeal to the wider audience at home 
$\rightarrow$ source of attributed proposition $=$ Other

$\rightarrow$ basis of Other's knowledge $=$ thought

$\rightarrow$ certainty of Other's knowledge $=$ medium $($ thought $)$

Taking into account the above comments on sourcing, the complete list of the different bases of evidence that occur in the text data is thus as follows: ${ }^{11}$

- PERCEPTION

- GENERAL KNOWLEDGE

- PROOF

- OBVIOUSNESS

- UNSPECIFIED

- HEARSAY ( source $=$ Other)

$-\quad$ MINDSAY $($ source $=$ Other $)$

It must be noted that the notion of sourcing does not just relate to attribution, but may also be relevant to PERCEPTION, concerning the identity of the one who perceives. I shall use the term Experiencer to refer to this type of source (to distinguish it from Sayers and Sensers as sources of utterances). Compare:

(13) MacDonald, dubbed the Queen of Tarts, looked distraught as the verdict was read out in a Paris court on her 44th birthday. (Express)

$\rightarrow$ source $=$ Self

$\rightarrow$ basis of Self's knowledge: PERCEPTION $($ Experiencer $=$ Self $)$

$\rightarrow$ certainty of knowledge $=$ high (looked $)$

(14) This is drug-scandal star Rio Ferdinand out shopping - on the day he was meant to have his dope test. The England ace, who claims he forgot about the test as he was moving house, was seen near Manchester's posh Harvey Nichols store. (Star)

$\rightarrow$ source $=$ Self

$\rightarrow$ basis of Self's knowledge: PERCEPTION by unnamed Experiencer (Self/Other)

$\rightarrow$ certainty of knowledge: high (was seen)

What is relevant here is the source or Experiencer of the PERCEPTION (rather than the source of the utterance itself: both examples are averrals: source $=$ Self $)$. In the first example, it is the writer him/herself who thinks that MacDonald looked distraught, whereas in the second example, it is presumably unnamed Others who saw Rio Ferdinand in Manchester, though the passive conceals the agent (it may in fact have been the writer him/herself). 
In news reportage, both examples of Experiencer:Self and of Experiencer:Other are frequent. The former often occur in the context of descriptions of news actors' mental states, e.g., She hung her head and looked utterly shocked (Express). Since mental states cannot normally be known to someone other than the Experiencer, this is necessary to justify their reporting. By pretending that these events are in fact observable phenomena, i.e., by mentioning sensory evidence for the existence of the respective mental state in the Experiencer's mind, the newspapers justify their report of them. Expressions of Experiencer:Other are also effective means of providing evidence for statements, and evaluating the reliability of attributed propositions, as in

(15) The England ace, who claims he forgot about the test as he was moving house, was seen near Manchester's posh Harvey Nichols store. And neighbors have revealed they didn't see the 24-year-old move into his new home until September 25-two days later. (Star)

where the perceptual evidence clearly contradicts the footballer's statements.

In news discourse, many propositions are also necessarily signaled as being based on HEARSAY or MINDSAY, since such discourse consists predominantly of 'embedded talk' (Bell 1991: 52). This means that the analysis of EP can become quite complex, as becomes apparent in the following examples:

(16) As Pelé, perhaps the greatest-ever footballer, said when he flew into Newcastle yesterday, many of the country's young stars appeared to be losing touch with the qualities that once made them role models. (Times)

$\rightarrow$ source of utterance $=$ Self $($ Writer $)$

$\rightarrow$ modified element $1=$ Pelé [is] the greatest-ever footballer

$\rightarrow$ basis of Self's knowing $=$ not explicitly marked

$\rightarrow$ certainty of knowledge $=$ low (perhaps)

$\rightarrow$ modified element $2=$ many of the country's young stars $\ldots$ models.

$\rightarrow$ basis of Self's knowledge $=$ HEARSAY

$\left(16^{\prime}\right)$ the country's young stars appeared to be losing touch with the qualities that once made them role models.

$\rightarrow$ source of attributed proposition $=$ Other

$\rightarrow$ basis of Other's knowing $=($ mental) PERCEPTION $($ appeared $)$

$\rightarrow$ certainty of Other's knowledge $=$ low (appeared)

$\rightarrow$ certainty of attributed proposition $=$ high (as Pelé $\ldots$ said $)$ 
In this example, the writer avers firstly that Pelé [is] the greatest-ever footballer, not giving information about the basis of this assessment, but telling us that his/her certainty of knowledge is low (perhaps). At the same time, s/he avers that the proposition (many of the country's young stars ... models) is based on HEARSAY. For these averrals the writer clearly is the source $($ source $=$ Self). Furthermore, the proposition (many ... models) is attributed to Pele (source $=$ Other), the basis of his knowledge is given as (mental) PERCEPTION, and his certainty of knowledge is classified as low (appeared). Additionally, the writer uses a structure that implies that Pelé is right in his assessment (as Pelé ... said; cf. Thompson 1994: 50). Indications of certainty can thus both relate to the Other's certainty of knowledge and to the Self's assessment concerning the certainty of the attributed proposition (Thompson [1994] mentions many examples for the latter, and much linguistic research on English for academic purposes has looked into this).

Another complex example involving EP is Example (17):

(17) During her trial she described herself as 'an excellent businesswoman' and the police have good reason to agree with that selfassessment. (Mail)

Let us for a moment treat this as meaning simply 'the police have good reason to say that she is an excellent businesswoman'. The source of this utterance is Self (it is an averral), but no information is given as to the basis of the source's knowledge that the police have good reason to ..., nor is there any explicit information concerning the certainty of Self knowledge. However, when we look at the attributed proposition ( source = Other) ('she is an excellent businesswoman'), we can find that the writer gives us the basis of the Other's knowledge as some sort of proof (the police have good reason to). Since proof is considered a good basis or evidence, the certainty of knowledge that is attributed to the police is rather high (and the writer appears to share their view).

Summing up, we can say that the analysis of EP becomes highly complex when attribution is considered, since expressions of EP can concern both attribution and averral. For this reason, it is convenient (and necessary) to distinguish between sourcing (who is Sayer, Senser, or Experiencer) and evidentiality (what is the basis of knowledge), and to consider to which aspect of the utterance expressions of EP relate.

\subsection{Based averrals}

Not only must a distinction be made between attributions (source $=$ Other) and averrals (source $=$ Self), a further difference must in fact be 
made between based and non-based averrals. ${ }^{12}$ Based averrals give some sort of indication about the evidential basis of the writer's averral without attributing propositions to an Other: Famously, John is an idiot is an example for a based averral (rather than the non-based John is an idiot).

In fact, there is gradience between based averrals and attributions, as seen in the following (invented) examples:

Attribution He said that Mr Duncan Smith was wrong.

Based averral Yesterday's poll of activists showed that Mr Duncan Smith was wrong.

Tests found that Mr Duncan Smith was wrong.

Non-based averral Mr Duncan Smith was wrong.

As suggested, attributions are based on what Sayers/Sensers said or thought (He said that), whereas based averrals can be premised on the writer's interpretation of data (a poll ... showed that/Tests found). The distinction is a very fine one and shows the gradience between attributions and some types of based averrals (those that are based on writers' interpretation of linguistic evidence). This overlap is explicable by the fact that both based averrals and attributions are part of the same phenomenon, evidentiality.

Moreover, there is an apparent perceived similarity of structures such as She revealed that I was wrong and It emerged that I was wrong. Again, we need to combine the concepts of sourcing and evidentiality in order to account for this, and the two questions to be addressed in this context are:

1. Who is the source of the utterance?

2. What is the nature of the basis of the utterance?

As we have seen, with attributions the source (of the attributed proposition) is Other, and the basis for the Self's knowledge of the (attributed) proposition is HEARSAY or MINDSAY. We could thus say that the basis is 'outside' the Self (it only involves the Self as hearer). Figure 1 visualizes these assumptions.

Similarly, with some based averrals, although the source seems to be the Self, the basis is also 'outside' the Self (see Figure 2).

$$
\text { Basis = 'outside' Self }\} \text { He thought I was wrong. (MINDSAY) }
$$

Figure 1. Attribution: Bases 'outside' Self 


$$
\begin{aligned}
& \text { Source }=\text { Self } / \\
& \text { Basis = 'outside' Self }
\end{aligned}\left\{\begin{array}{l}
\text { It emerged that } \\
\text { There was proof that } \\
\text { Notoriously, }
\end{array}\right.
$$

I was wrong (UNSPECIFIED)

I was wrong (PROOF)

I was wrong (GENERAL

KNOWLEDGE)

Figure 2. Averrals: Bases 'outside' Self

$$
\begin{aligned}
& \begin{array}{l}
\text { Source }=\text { Self } \\
\text { Basis = 'inside' Self }
\end{array} \\
& \begin{array}{l}
\text { Clearly, } \\
\text { It appears that } \\
\text { It looks like }
\end{array}
\end{aligned}
$$

Figure 3. Averrals: Bases 'inside' Self

Even though with these examples (see Figures 1 and 2) the writer does not attribute a proposition to an explicit Other, s/he says that some external basis exists on which his/her knowledge (that s/he was wrong) is based. The writer is still involved, however, because it is evident that $\mathrm{s} / \mathrm{he}$ had access to this external evidence. The external evidence seems to be construed as publicly accessible: it emerged that indicates that the proposition 'becomes known' in general, notoriously also signals common knowledge, and there was proof that presumably means that this proof is theoretically verifiable by the general public. The similarity of these types of based averrals to attributions can thus be explained by reference to the fact that both involve external bases.

With other based averrals, the basis is not construed as external and publicly accessible, but rather resides in the writer's own subjective experience. This seems to be the case with at least some expressions of PERCEPTION and OBVIOUSNESS (see Figure 3).

In Figure 3, the writer tells us that the proposition is obvious from his/her point of view (though some externality is involved in that clearly implies persuasively that the proposition is obvious in general, not requiring evidence), as well as that the basis of his/her knowledge is his/her own mental or sensory perception. With other expressions of perception (sign that), however, the evidential basis may be construed as more external and objective. There is thus no direct correlation between the type of basis and the degree of subjectivity: rather, this depends both on the evidential involved and on the context.

We could interpret such structures as being situated on a cline of subjectivity, in terms of the explicitness in which the speaker's presence is signaled in an utterance (Verstraete 2001: 1513). The more the speaker's presence is explicit, the more subjectified the utterance; and the less the speaker's presence is explicit in the utterance, the more objectified the 
utterance. This notion has for instance been applied to modality in systemic functional linguistics, where the degree of subjectivity involved depends on its realization as projecting mental clause with $I$ as Senser, modal adverb, relational clause, or modal verb (see Table 2 in Appendix). The concept also figures (in a different way) in cognitive linguistics (e.g., Sanders and Spooren 1997; Mushin 2001), where it is assumed that ' $[t]$ he more the conceptualiser [the speaker as Experiencer] is "presupposed" in the construal of a scene, the more subjectified is the utterance' (Mushin 2001: 9).

In contrast, I would argue that the subjectivity in the examples above is not directly signaled by type of realization but more implicitly marked by sourcing and the construal of the evidence as internal (more subjective) or external (more objective). The dimension of subjectivity is defined in terms of Self access versus Other access to bases of information:

The alternatives within this dimension could then be phrased as follows: one pole involves the speaker's indication that (s)he alone knows (or has access to) the evidence and draws conclusions from it; the other pole involves his/her indication that the evidence is known to (or accessible by) a larger group of people who share the same conclusion based on it. (Nuyts 2001: 393, on subjectivity and epistemic modals)

Concerning sourcing and evidentiality, we can then argue that attributions and based averrals are situated on a cline of subjectivity, depending on whether the sources and bases of propositions are construed as external or internal (see Figure 4).

It is important to point out that the distinction between internal and external evidence is not equivalent to the difference between direct and indirect evidence (Willett 1988: 57): both direct (e.g., sensory) and indirect (e.g., inferring) types of bases may be internal rather than external.

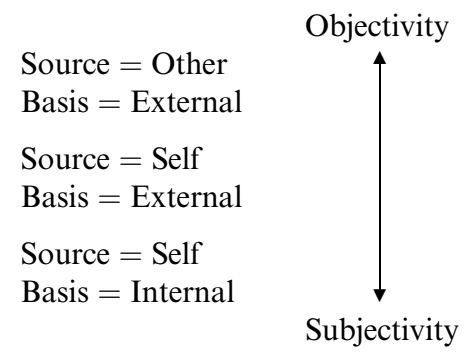

Figure 4. Subjectivity and objectivity 


\subsection{Backings}

What is interesting to note is that we can also find in the corpus a range of expressions that do not refer to a specific type of basis (such as PERCEPTION, OBVIOUSNESS, Or HEARSAY), but rather relate to different backings for the speaker's knowledge (a term adopted from Toulmin 1969 who applies it, slightly differently, to argumentation). Such linguistic items indicate that a backing of some sort may be found in their context. For example, expressions such as meaning that/that means, acknowledgement that, and warning that all appear to be related to the pattern ' $\mathrm{X}$ represents the reason why I think that $\mathrm{Y}$ ' or ' $\mathrm{X}$ represents the backing for Y':

(18) Police have never managed to trace her money, believed to be stashed in secret bank accounts and offshore trusts, meaning that MacDonald will be free to resume her life of luxury when she becomes eligible for parole in ten months' time. (Mail)

(19) After MacDonald was led away in handcuffs, Emmanuel Marsigny, her lawyer, denounced what he said was the injustice of the sentence and promised to appeal. That means the trial will be staged again in a higher court, with possible outcomes ranging from acquittal to a more severe sentence. (Times)

(20) Mr Maclean's decision to call in the rebels - the chief whip does not normally speak publicly — was an acknowledgement that the leadership is taking the threat of a challenge seriously. (Telegraph)

(21) The dissident MPs received a further warning that a lengthy leadership contest this winter could wreck the party's attempts to raise money to fight the next election. Lord Ashcroft, the former party treasurer, told The Daily Telegraph that big donors were holding back because of the sniping. He said the party was in the red and had to raise $£ 12$ million to fight the election. (Telegraph)

In all examples, it is indicated that the writer's knowledge is based on some backing that is mentioned in the context: in Example (18), the police's failure to find Margaret MacDonald's money, and the belief that it is hidden away somewhere are taken as the backing for the writer's (certain) conclusion that MacDonald will be free to resume her life of luxury. In Example (19), it is Emmanuel Marsigny's declaration that is regarded as a sufficient backing for the writer's (certain) speculation that the trial 
will be staged again in a higher court, whereas in Example (20), the writer uses an assessment of an action as unusual (not normally) as providing a backing for the judgment that Mr. Maclean's decision is an acknowledgement that the leadership is taking the threat of a challenge seriously. The writer reconciles the cognitive dissonance that results from his/her knowledge that the chief whip does not usually speak in public, and his actual decision to call in the rebels, and thus to speak in public (which deviates from the writer's background knowledge about the chief whip's normal behavior) by concluding that this means that the leadership is taking the threat of a challenge seriously (a mental state that cannot be observed directly). Example (21) is even more complex: the dissident MPs are here represented by the writer as having been given a warning, 'an advance notice of something that will happen' (COBUILD 2001), namely that $a$ lengthy leadership contest this winter could wreck the party's attempts to raise money to fight the next election. However, I would argue that warning in this context does not refer to an illocutionary act (as in he warned them that 'a lengthy leadership contest this winter could wreck the party's attempts to ...'). Rather, the propositions attributed to Lord Ashcroft (big donors were holding back because of the sniping; the party was in the red and had to raise $£ 12$ million to fight the election) are interpreted by the writer as signaling that the contest could damage the party financially. They represent the backing for his/her conclusion (which, as indicated by could, is of low certainty). This is very clearly an averral rather than an attribution though it seems to 'disguise itself' as an attribution by using a noun that can easily be interpreted as attributing on a casual reading (warning that).

That backings are not the same as bases becomes clear when we look at the following examples, which involve both backings and bases:

(22) General John de Chastelain, the head of the Independent International Commission on Decommissioning had added to the sense of [basis: PERCEPTION] choreography by saying that the IRA had completed a third act of decommissioning [backing]. (Telegraph)

(23) The clearest sign that [basis: PERCEPTION] the leadership realises the danger is not yet past came when it confirmed that Mr Maclean is calling in the plotters [backing]. (Times)

(24) Mr Palios's actions [backing] are a sign of [basis: PERCEPTION] his determination. (Guardian)

In Example (22), de Chastelain's/the leadership's utterances (saying that ...) are given as a backing for why there is a sense of (basis: PERCEPTION) 
choreography. In Examples (23) and (24), the leadership's confirmation that Mr Maclean is calling in the plotters and Mr Palios's actions are interpreted by the writer as a sign (basis: PERCEPTION) that the leadership realises the danger is not yet past/of his determination (again, mental states that cannot be directly observed). In other words, the knowledge that $\mathrm{Mr}$ Palios is determined is based on an inference by the writer that is backed by his interpretation of Mr Palios's actions.

These are very complex cases of epistemological positioning, which point to the fact that EP in context deserves further examination (perhaps in relation to Hoey's 1983 concept of clause relations), and may also have to take into account research on argumentation (e.g., Toulmin 1969).

\section{Conclusion: Elements of EP}

Despite the fact that there is no morphologized system of evidentiality or EP in the English language, it has become clear that the possibilities to mark assessments concerning knowledge in English are highly complex. EP is hence a phenomenon that deserves more attention even in languages that allow only its lexical expression. Some of its aspects have been outlined in this paper, which offers a preliminary exploration of EP in English. Even though I could only offer a very short and cursory introduction to EP, what seems clear so far is that it is necessary to consider at least the following elements (together with mirativity and extent) in any analysis of EP in naturally occurring data (see Figure 5).

Further research is necessary to refine this system of EP with the help of more text-driven and corpus-driven analyses of different registers and

Who is the source of a proposition (sourcing): Self or Other?

What is the basis of (Self/Other) knowledge (evidentiality): HEARSAY, PERCEPTION, etc.?

Is the basis construed as more objective (external) or more subjective (internal) (subjectivity)?

How certain is the knowledge of Self or Other? (certainty)

How is certainty of knowledge expressed $\backslash \begin{aligned} & \text { directly/explicitly (modality)? } \\ & \text { indirectly (evidentiality)? }\end{aligned}$

What are the reasons for (Self/Other) knowledge (backing)?

Figure 5. Aspects to be considered in the analysis of EP 
text types (cf. Hunston 2000 on bases in persuasive texts). After all, the proposed system of EP derives only from the corpus at hand, and further refinements could be added. Areas that are delimited for future research include the classification of sources (for proposals, see White 2001: 4-5), the connection between EP and the speaker-hearer relation, and the pragmatics of expressions of EP. For instance, there is no implication that expressions of certainty necessarily reflect the speaker's/writer's actual certainty, or that speakers/writers truthfully mark the sources and bases of their knowledge. Rather, expressions of EP are presumably used for a variety of pragmatic and rhetorical purposes in naturally occurring discourse (see Pomerantz 1984; Fox 2001; Downing 2001; Mushin 2001; Bednarek 2006b on the pragmatics of evidentiality and research on epistemic stance in academic discourse).

\section{Appendix: Tables}

Table 1. The corpus

\begin{tabular}{lc}
\hline Newspaper & Number of words \\
\hline Broadsheet & \\
The Financial Times & 4,434 \\
The Guardian & 7,921 \\
The Independent & 8,599 \\
The Times & 8,845 \\
The Daily Telegraph & 7,605 \\
Subtotal & 37,404 \\
Tabloid & \\
The Sun & 5,965 \\
The Star & 3,949 \\
The Daily Mail & 8,826 \\
The Daily Mirror & 6,258 \\
The Daily Express & 7,798 \\
Subtotal & 32,796 \\
Total & 70,300 \\
\hline
\end{tabular}

Note: The corpus consists of 100 'hard' news stories covering ten topics taken from ten British national newspapers. (A more detailed description of the corpus is given in Bednarek 2006b). 


\section{Monika Bednarek}

Table 2. Subjective and objective modality

\begin{tabular}{lll}
\hline Modality & Examples \\
\hline Explicit & Objective & it is certain $(150)$, it is probable, it isn't possible (615) \\
Implicit & Objective & certainly $(150)$, probably, surely (615) \\
Explicit & Subjective & I'm certain that (150), I guess, I suppose, I don't think, I know \\
Implicit & Subjective & (614-615) \\
must $(150)$, could, may (615)
\end{tabular}

Cf. Halliday and Matthiessen (2004: 150, 614-615).

Table 3. Categorization of certainty of knowledge

\begin{tabular}{lll}
\hline Certainty & Modality & Evidentiality \\
\hline High & will & $\begin{array}{l}\text { seen, looked } \\
\text { thought } \\
\text { Medium }\end{array}$ \\
Low & perhaps, could & appeared \\
\hline
\end{tabular}

Table 4. Chafe's (1986) categories of evidentiality and their treatment in this paper

\begin{tabular}{|c|c|c|}
\hline Categories of evidentiality & Examples in Chafe (1986) & Treatment in this paper \\
\hline Reliability & $\begin{array}{l}\text { maybe, probably, certainly, } \\
\text { might, may, possibly, } \\
\text { undoubtedly, surely }\end{array}$ & certainty of knowledge \\
\hline Markers of belief & think, guess, suppose & $\begin{array}{l}\text { evidentiality: mindsay (if } \\
\text { attributed to Other) }\end{array}$ \\
\hline Markers of induction & must, seem & $\begin{array}{l}\text { certainty of knowledge } \\
\text { (must); evidentiality: } \\
\text { perception (seem) }\end{array}$ \\
\hline Markers of hearsay & $\begin{array}{l}\text { people say, they say, I've } \\
\text { been told, Sarah told me }\end{array}$ & evidentiality: hearsay \\
\hline Markers of deduction & should, can, could, would & certainty of knowledge \\
\hline $\begin{array}{l}\text { Source of knowledge: } \\
\text { markers of sensory } \\
\text { evidence }\end{array}$ & see, hear, feel & evidentiality: perception \\
\hline $\begin{array}{l}\text { Matching knowledge } \\
\text { against expectations }\end{array}$ & $\begin{array}{l}\text { of course, oddly enough, in } \\
\text { fact, actually, at least, } \\
\text { even, only, but, however, } \\
\text { nevertheless }\end{array}$ & mirativity \\
\hline $\begin{array}{l}\text { Matching knowledge } \\
\text { against verbal resources }\end{array}$ & sort of, kind of & not discussed \\
\hline
\end{tabular}


Table 5. Rooryck's (2001) categories of evidentiality and their treatment in this paper

\begin{tabular}{|c|c|c|}
\hline Categories & Examples & Treatment in this paper \\
\hline Nonvisual sensorial & feel, sense & perception \\
\hline $\begin{array}{l}\text { Sensorial inferential, visual } \\
\text { deduction }\end{array}$ & I see & perception \\
\hline Sensory evidence, hearsay & $\begin{array}{l}\text { I hear/they say/(so), I'm } \\
\text { told }\end{array}$ & hearsay \\
\hline Quotative & Sarah said & hearsay \\
\hline $\begin{array}{l}\text { Memory/circumstantial } \\
\text { inferential }\end{array}$ & realize/found out & $\begin{array}{l}\text { mindsay (if attributed to } \\
\text { Other) }\end{array}$ \\
\hline $\begin{array}{l}\text { Unspecified source, } \\
\text { circumstantial inferential }\end{array}$ & $\begin{array}{l}\text { it seems, it appears, it turns } \\
\text { out }\end{array}$ & $\begin{array}{l}\text { perception (seem, appear) } \\
\text { unspecified (turn out) }\end{array}$ \\
\hline Speculative & $\begin{array}{l}\text { believe/think/guess/ } \\
\text { presume/suspect/assume/ } \\
\text { take it/gather }\end{array}$ & $\begin{array}{l}\text { mindsay (if attributed to } \\
\text { Other) }\end{array}$ \\
\hline $\begin{array}{l}\text { Surprisal: to attenuate } \\
\text { hearer's surprise }\end{array}$ & I'm afraid, I'm sorry to say & $\begin{array}{l}\text { mindsay (if attributed to } \\
\text { Other) }\end{array}$ \\
\hline Evaluative: (dis)approval & $\begin{array}{l}\text { I'm sorry/happy to say/tell } \\
\text { you }\end{array}$ & $\begin{array}{l}\text { mindsay (if attributed to } \\
\text { Other) }\end{array}$ \\
\hline Surprisal/admirative & can you imagine! & mirativity \\
\hline $\begin{array}{r}\text { Personal responsibility for } \\
\text { assertion/witness report }\end{array}$ & tell s.o./swear & $\begin{array}{l}\text { hearsay (if attributed to } \\
\text { Other) }\end{array}$ \\
\hline Concessive & admit/confess & $\begin{array}{l}\text { hearsay (if attributed to } \\
\text { Other) }\end{array}$ \\
\hline Current relevance & $\begin{array}{l}\text { (you) understand? you } \\
\text { know? }\end{array}$ & not discussed \\
\hline
\end{tabular}

Note: Many of the examples mentioned by Chafe and Rooryck involve 1st person evidentials, whereas my data includes only 3 rd person evidentials (because I have excluded quoted speech from the analysis). This distinction, however, may entail important functional differences: for example, those expressions that would be classified as MINDSAY or HEARSAY when they concern attributions (believe, realize, say) are obviously not MINDSAY/HEARSAY if Self is the source (on utterances such as I have to say I very much doubt it, cf. Hunston 2000: 190).

\section{Notes}

* I would like to thank Dr. Brigitta Mittmann, Prof. Wolfram Bublitz, and two anonymous reviewers very much for their helpful comments on an earlier version of this paper.

1. Knowledge in itself is a concept that is notoriously difficult to define (and no attempt to do so will be undertaken here). Rather, I use knowledge in a pre-theoretical sense, referring to (true or false) information of which speakers/writers are aware, and to which they refer in their propositions (including those encapsulated in nominalizations).

2. For a brief history on evidentiality see, e.g., Mushin (2001), Aikhenvald (2004), Dendale and Tasmowski (2001), Rooryck (2001).

3. Aikhenvald (2004: 63-64) identifies the following repeated semantic dimensions of evidentiality across languages: 
I. VISUAL: covers information acquired through seeing.

II. NON-VISUAL SENSORY: covers information acquired through hearing, and is typically extended to smell and taste, and sometimes also to touch.

III. INFERENCE: based on visible or tangible evidence, or result.

IV. ASSUMPTION: based on evidence other than visible results: this may include logical reasoning, assumption, or simply general knowledge.

V. HEARSAY: for reported information with no reference to those it was reported by.

VI. QUOTATIVE: for reported information with an overt reference to the quoted source.

(For other cross-linguistic classifications of evidentiality see, e.g., Willett 1988; Rooryck 2001).

4. Cf. Pomerantz (1984) on using evidence in conversation; Chafe (1986) on differences in evidentiality between conversation and academic writing; Traugott (1989) on the development of epistemic (including evidential) meanings in English; Biber and Finegan (1989) and Biber et al. (1999) on epistemic stance (including evidentiality) in different registers of English from a grammatical perspective; Norrick (1995) on the evidential function of hunh-tags in conversation; Ramat (1996) on evidential adverbs (including English) from a typological perspective; Watson (1999) on evidentiality and affect in Australian fiction; King and Nadasdi (1999) on evidentiality and code-switching between French and English in Canada; de Haan (1999) on the distinction between epistemic modality and evidentiality; Downing (2001) on surely as a marker of evidentiality and stance; Fox (2001) on the creation and maintenance of authority by means of evidentiality in American-English conversation; Mushin (2001) on evidentiality and epistemological stance in English and other languages; Neff et al. (2003) on native and non-native speakers' uses of evidentiality; and Precht (2003) on evidentiality in British and American conversation.

5. Furthermore, evidentiality is here used as the cover term for both the grammatical and the lexical expression of the basis of information. Although there may be some arguments for distinguishing between the two (see in particular Aikhenvald 2003, 2004, who argues strongly against including lexical expressions as evidentiality), both realizations arguably have the same kind of meaning. On a higher, functional level, it is not unreasonable to include both phenomena under one label (cf. also Ramat 1996; Mushin 2001: 57). This decision is supported by the fact that some evidentials are the result of a grammaticization of lexical expressions of evidentiality (Aikhenvald 2004: chapter 9).

6. Whether or not mirativity (un/expectedness) encodes epistemological considerations is debatable. For example, Biber and Finegan claim that their category of amazingly adverbials (e.g., oddly, amazingly) signals 'attitudes towards the content independent of its epistemological status' (Biber and Finegan 1988: 8), whereas Chafe (1986: 263) notes that such expressions concern 'the match between a speaker or writer's knowledge and [...] expectations'. In fact, as I have argued elsewhere (Bednarek 2006a), such linguistic items can be considered indicators of frame knowledge, and are hence part of the analysis of EP. However, I think it is more problematic to include hedges (Chafe 1986) in EP, but this will not be considered here. It might also be possible to consider the realm of knowledge in EP, i.e., whether the knowledge is factual or fictive (see Mushin 2001), perhaps in connection with what Hunston (2000: 186) calls the status of propositions: 'the alignment of statement and world'.

7. The term modal is used in a narrow sense here, for expressions that indicate only certainty of speaker/writer knowledge. The relation between modality and evidentiality is far too complex to discuss here (cf. Dendale and Tasmowski 2001: 342), and some researchers argue that modal expressions do mark evidentiality (Chafe 1986). For 
arguments in favor of the distinction between modality and evidentiality, see de Haan (1999), Aikhenvald (2004).

8. In contrast, we might classify as text-based all analyses that adopt a specific framework (e.g., SFL) and apply this to the analysis of texts. In fact, what Halliday notes with respect to corpus-based and corpus-driven research is also true for text-based and textdriven analysis: the two approaches represent a continuum rather than a strict dichotomy, and much research is situated somewhere in between (Halliday 2004: 24). Thus, the methodology adopted in this paper is not wholly text-driven, but partly theorydriven (i.e., it discusses previous research into evidentiality, and uses this as a springboard for the analysis).

9. For the analyses in this paper, the categorization system outlined in Table 3 (Appendix) was used (though it must be pointed out that a scale of certainty is involved rather than discrete values). Such a categorization is always subjective to a certain extent, but there is perhaps a case for arguing that will, see, look express a higher degree of certainty than perhaps, could, and appeared, which seem rather similar in their epistemic modal meaning.

10. Although it is theoretically impossible to know what someone else thinks or feels, this is quite common in fiction when someone's thoughts are represented with quotation marks (in line with the convention of the omniscient narrator). In news discourse, the case is somewhat different: although there is a mental-state verb (thought) indicating mindsay, the conventional expectation is that the directly quoted material ('mannered') has in fact actually been uttered by a Sayer (thus indicating Hearsay). Nevertheless, the distinction between HEARSAY and MINDSAY seems theoretically valid, since it is reflected in different attributing expressions.

11. These categories are not unrelated to the categories of evidentiality mentioned by Aihkenvald (see Note 3 in this paper), Chafe (1986), and Rooryck (2001) (see Tables 4 and 5 in Appendix), a fact that supports the decision to regard grammatical and lexical evidentiality as part of the same phenomenon. Universally, it looks like more or less the same bases can be referred to in different languages, whether lexically or morphologically. How these bases are classified is to some extent a matter of subjective interpretation on the part of the analyst. For instance, I do not distinguish in this paper between mental perception (inference) and sensory perception, because the line between such expressions is often blurred in actual discourse: it is frequently not clear whether the information is based on (a) a sensory perception, (b) an inference based on sensory evidence, or (c) simply an inference ('mental perception').

12. Hunston (2000) calls such instances sourced averrals but I prefer the term based averral, because the defining characteristics of averral is that it is not attributed to another source. (Hunston appears to use the term source in the way it is usually used in studies of evidentiality, but, as we have seen, it might be useful to distinguish carefully between sources and bases of propositions.)

\section{References}

Aikhenvald, A. (2003). Evidentiality in typological perspective. In Studies in Evidentiality, A. Aikhenvald and R. M. W. Dixon (eds.), 1-32. Amsterdam/Philadelphia: John Benjamins. - (2004). Evidentiality. Oxford: Oxford University Press.

Aikhenvald, A. and Dixon, R. M. W. (eds.) (2003). Studies in Evidentiality. Amsterdam/ Philadelphia: John Benjamins. 
Anderson, L. B. (1986). Evidentials, paths of change and mental maps: Typologically regular asymmetries. In Evidentiality: The Linguistic Coding of Epistemology, W. Chafe and J. Nichols (eds.), 273-312. Norwood, NJ: Ablex.

Bednarek, M. (2006a). Evaluation and cognition: Inscribing, evoking and provoking opinion. In Language and Memory: Aspects of Knowledge Representation, H. Pishwa (ed.), 187-221. Berlin/New York: Mouton de Gruyter.

-(2006b). Evaluation in Media Discourse. Analysis of a Newspaper Corpus. (Research in Corpus and Discourse.) London/New York: Continuum.

Bell, A. (1991). The Language of News Media. Oxford: Blackwell.

Biber, D. and Finegan, E. (1988). Adverbial stance types in English. Discourse Processes 11: $1-34$.

-(1989). Styles of stance in English: Lexical and grammatical marking of evidentiality and affect. Text 9: 93-124.

Biber, D., Johansson, S., Leech, G., Conrad, S., and Finegan, E. (1999). Longman Grammar of Spoken and Written English. London: Longman.

Bybee, J. and Fleischman, S. (1995). Modality in grammar and discourse. An introductory essay. In Modality in Grammar and Discourse, J. Bybee and S. Fleischman (eds.), 1-14. Amsterdam: John Benjamins.

Caffi, C. and Janney, R. W. (1994). Toward a pragmatics of emotive communication. Journal of Pragmatics 22: 325-373.

Chafe, W. (1986). Evidentiality in English conversation and academic writing. In Evidentiality: The Linguistic Coding of Epistemology, W. Chafe and J. Nichols (eds.), 261-272. Norwood, NJ: Ablex.

Chafe, W. and Nichols, J. (eds.) (1986). Evidentiality: The Linguistic Coding of Epistemology. Norwood, NJ: Ablex.

COBUILD (2001). Collins COBUILD English Dictionary for Advanced Learners, CD-ROM (Lingea Lexicon 2002, version 4.05). London: HarperCollins.

Comrie, B. (2000). Evidentials: Semantics and history. In Evidentials. Turkic, Iranian and Neighbouring Languages, L. Johanson and B. Utas (eds.), 1-14. Berlin/New York: Mouton de Gruyter.

de Haan, F. (1999). Evidentiality and epistemic modality: Setting boundaries. Southwest Journal of Linguistics 18 (1): 83-101.

—(2001). Evidentiality bibliography. URL:〈http://www.u.arizona.edu/ fdehaan/papers/ evidbib.html $\rangle$ [accessed on 17 May 2005].

DeLancey, S. (1997). Mirativity: The grammatical marking of unexpected information. Linguistic Typology 1: 33-52.

Dendale, P. and Tasmowski, L. (eds.) (2001). Journal of Pragmatics (Special issue: Evidentiality) 33 (3).

Downing, A. (2001). 'Surely you knew!' Surely as a marker of evidentiality and stance. Functions of Language 8 (2): 253-285.

Du Bois, J. W. (1986). Self-evidence and ritual speech. In Evidentiality: The Linguistic Coding of Epistemology, W. Chafe and J. Nichols (eds.), 313-336. Norwood, NJ: Ablex.

Fox, B. A. (2001). Evidentiality: Authority, responsibility, and entitlement in English conversation. Journal of Linguistic Anthropology 11 (2): 167-192.

Givón, T. (1982). Evidentiality and epistemic space. Studies in Language 6 (1): 23-49.

Greenbaum, S. (1969). Studies in English Adverbial Usage. London: Longman.

Guentchéva, Z. (ed.) (1996). L'Énonciation Médiatisée. Louvain/Paris: Peeters.

Halliday, M. A. K. (2004). The spoken language corpus: A foundation for grammatical theory. In Advances in Corpus Linguistics. Papers from the 23rd International Conference 
on English Language Research on Computerized Corpora, K. Aijmer and B. Altenberg (eds.), 11-39. Amsterdam/New York: Rodopi.

Halliday, M. A. K. and Matthiessen, M. I. M. (2004). An Introduction to Functional Grammar. London: Arnold.

Hill, J. H. and Irvine, J. T. (1993a). Introduction. In Responsibility and Evidence in Oral Discourse, J. H. Hill and J. T. Irvine (eds.), 1-23. Cambridge: Cambridge University Press.

—(eds.) (1993b). Responsibility and Evidence in Oral Discourse. Cambridge: Cambridge University Press.

Hoey, M. (1983). On the Surface of Discourse. London: Allen \& Unwin.

Hunston, S. (2000). Evaluation and the planes of discourse: Status and value in persuasive texts. In Evaluation in Text: Authorial Stance and the Construction of Discourse, S. Hunston and G. Thompson (eds.), 176-207. Oxford: Oxford University Press.

Jacobsen Jr., W. H. (1986). The heterogeneity of evidentials in Makah. In Evidentiality: The Linguistic Coding of Epistemology, W. Chafe and J. Nichols (eds.), 3-28. Norwood, NJ: Ablex.

Jakobson, R. (1971 [1957]). The Selected Writings of Roman Jakobson, Vol. 2.130-147. The Hague: Mouton.

Johanson, L. and Utas, B. (2000). Evidentials. Turkic, Iranian and Neighbouring Languages. Berlin/New York: Mouton de Gruyter.

King, R. and Nadasdi, T. (1999). The expression of evidentiality in French-English bilingual discourse. Language in Society 28: 355-365.

Mushin, I. (2001). Evidentiality and Epistemological Stance. Narrative Retelling. Amsterdam/ Philadelphia: John Benjamins.

Neff, J., Dafouz, E., Díez, M., Martínez, F., Prieto, R., and Rica, J. P. (2003). Evidentiality and the construction of writer stance in native and non-native texts. In Language and Function. To the Memory of Jan Firbas. (Studies in Functional and Structural Linguistics 49.), J. Hladký (ed.), 223-235. Amsterdam/Philadelphia: John Benjamins.

Norrick, N. R. (1995). Hunh-tags and evidentiality in conversation. Journal of Pragmatics 23 (6): 687-692.

Nuyts, J. (2001). Subjectivity as an evidential dimension in epistemic modal expressions. Journal of Pragmatics 33: 383-400.

Pomerantz, A. (1984). Giving a source or basis: The practice in conversation of telling 'How I know'. Journal of Pragmatics 8: 607-625.

Precht, K. (2003). Stance moods in spoken English: Evidentiality and affect in British and American conversation. Text 23: 239-257.

Ramat, P. (1996). 'Allegedly, John is ill again': Stratégies pour le médiatif. In L'Énonciation Médiatisée, Z. Guentchéva (ed.), 287-298. Louvain/Paris: Peeters.

Rooryck, J. (2001). State-of-the-article. Evidentiality (part 1). Glot International 5 (4): 125 133.

Sanders, J. and Spooren, W. (1997). Perspective, subjectivity, and modality from a cognitive linguistic point of view. In Discourse and Perspective in Cognitive Linguistics, W.-A. Liebert, G. Redeker, and L. Waugh (eds.), 85-112. Amsterdam: John Benjamins.

Sinclair, J. M. (1988). Mirror for a text. Journal of English and Foreign Languages 1: 15-44.

Stubbs, M. (1996). Text and Corpus Analysis. Oxford: Blackwell.

Sweetser, E. E. (1984). Semantic Structure and Semantic Change: English Perception-Verbs in an Indo-European Context. Trier: L.A.U.T. (Linguistics Agency University of Trier).

Thompson, G. (1994). Collins COBUILD English Guides 5: Reporting. London: Harper Collins.

Tognini-Bonelli, E. (2001). Corpus Linguistics at Work. Amsterdam: John Benjamins.

Toulmin, S. E. (1969). The Uses of Argument. Cambridge: Cambridge University Press. 


\section{Monika Bednarek}

Traugott, E. C. (1989). On the rise of epistemic meanings in English: An example of subjectification in semantic change. Language 65: 31-55.

Verstraete, J.-C. (2001). Subjective and objective modality: Interpersonal and ideational functions in the English modal auxiliary system. Journal of Pragmatics 33 (10): 15051528.

Watson, G. (1999). Evidentiality and affect: A quantitative approach. Language and Literature 8 (3): 217-140.

White, P. R. R. (2001). Intertextuality. Manuscript (word processor version). URL: 〈http:// www.grammatics.com/appraisal $>$ [accessed on 3 January 2005].

Willett, T. (1988). A cross-linguistic survey of the grammaticalization of evidentiality. Studies in Language 12: 51-97.

Monika Bednarek is Lecturer of English linguistics at the University of Augsburg (currently Visiting Academic at the University of Sydney) with research interests in corpus linguistics, cognitive linguistics, pragmatics, and text linguistics. Specific interests include cohesion and coherence, frames, media language, evidentiality, and evaluation. Her Ph.D. thesis was concerned with the evaluative style of British broadsheet and tabloid publications. She has published on frames, evaluation, and media language. Address for correspondence: Department of Linguistics, University of Sydney, Transient Building, NSW 2006, Sydney, Australia 〈Monika.Bednarek@phil.uni-augsburg.de〉. 